\title{
Research on the Role of Mobile Learning Technology in Promoting Deep Learning of College Students
}

\author{
Xiangsen Liu, Zhenzhen Ye, Dongmei Jiang* \\ Hainan Medical University, Haikou 571101, Hainan, China. \\ E-mail: 627199205@qq.com
}

Fund Project: China undergraduate innovation and entrepreneurship training grogram,2019 (X201911810168)\&Teaching innovation project of Hainan Medical University,2020 (HYBB202063)

\begin{abstract}
As the primary productive force, education plays a huge role in the development of modern society. Traditional educational activities mainly focus on the teaching of students' superficial knowledge and skills, which are no longer able to meet the current society's demand for talents. At present, it is required to promote the development of in-depth thinking of college students, stimulate their innovation and creativity, and enable students to better contribute to social production. Therefore, it is very important to introduce the concept of deep learning for college students and establish a student-based teaching model. The author mainly uses mobile learning technology to analyze the functional role of mobile learning technology in promoting deep learning activities for college students, and proposes ways to effectively grasp mobile learning technology in future university informatization education activities.
\end{abstract}

Keywords: Mobile Learning Technology; College Students; Deep Learning; Role Analysis

With the further development of science and technology, society is gradually entering an era of profound changes. All walks of life can gain more competitive advantages only if they master in-depth technical means. As an important stage of social development, education is required to vigorously cultivate and improve students' learning ability, build a good learning foundation for college students, and broaden their horizons for deep and continuous learning. Only in this way can college students get closer to the development trend of various industries and better embrace the future.

\section{Mobile learning technology and deep learning analysis}

\subsection{Mobile learning technology}

First, the connotation of mobile learning technology. Mobile learning technology is a new educational method based on the continuous advancement of educational information technology. With the implementation of the concept of information education and the rapid development of various mobile terminal technologies, mobile learning technology has officially become an important means in education. In higher education activities, mobile learning technology relies on rich educational resources, information-based teaching concepts, and diversified teaching methods to greatly meet the needs of college students for independent and life-long learning. For example, in university education activities, the diversified and globalized educational characteristics of mobile learning have greatly cultivated students' ability to form higher $r$ thinking, use information platforms to carry out various practical exploration activities, and constantly discover problems in learning and practice to analyze and solve problems. Therefore, in the education and teaching activities of college students in the new era, mobile learning technology plays a vital role.

Second, the characteristics of mobile learning technology. As an emerging teaching technology, mobile learning technology has the characteristics of not being restricted by time and space. First of all, mobile learning technology can

Copyright (C) 2020 Xiangsen Liu et al

doi: 10.18282/le.v9i6.1299

This is an open-access article distributed under the terms of the Creative Commons Attribution Non-Commercial License

(http://creativecommons.org/licenses/by-nc/4.0/), which permits unrestricted non-commercial use, distribution, and reproduction in any medium, provided the original work is properly cited. 
create a convenient learning environment for college students. In traditional teaching activities for college students, students can only complete the course content within a limited time span, and classroom teaching interaction is greatly affected by the space-time environment. However, under the influence of various mobile intelligent terminal devices, college students can now engage in learning, communication and interaction anytime and anywhere, and the convenience of mobile learning has been significantly improved. Secondly, mobile learning technology can provide college students with fragmented learning resources. According to the traditional teaching plan, the professional learning of college students must be able to be carried out step by step in accordance with certain teaching arrangements. The lack of a certain link will cause the student's learning efficiency to slow down. With the support of mobile learning technology, the current professional teaching activities for college students will fragment teaching resources, and all knowledge points can be presented independently. In the learning process, students only need to randomly mobilize each knowledge point according to their learning progress to achieve the overall shaping of learning activities. It can be said that fragmented teaching resources have improved students' learning efficiency to a certain extent. But at the same time, fragmented learning can easily make students to form shallow learning, which is not conducive to students' in-depth exploration of various knowledge points.

\subsection{The connotation of deep learning}

Deep learning is a new learning concept proposed in the 1950s. It corresponds to surface learning. The main evaluation criterion is the ability to develop critical learning. That is, the student group who develops in-depth learning can develop the new and old knowledge systems in a thoughtful way, so as to improve their ability to solve problems and make decisions. In the current era, the future development of society is moving towards integrated development. Only when deep learning activities are launched can new ideas and directions for the progress and development of human society be provided. Therefore, we must pay attention to the cultivation of students' deep learning ability in higher education activities. Developing in-depth learning education for college students has become the focus of the current educational reform of colleges and universities.

\section{Analysis of the role of mobile learning technology in deep learning of college students}

From the analysis of mobile learning technology and deep learning concepts carried out above, it can be seen that in order to play an effective role of mobile learning technology in the education activities of college students, it must be able to combine the development characteristics of the two and make full use of the advantages of mobile learning technology. Based on the characteristics of fragmentation, decentralization and rapidity, based on the goals and requirements of deep learning, a brand-new teaching system for college students is designed to fundamentally play the active role of mobile learning technology in college students' deep learning. The specific implementation path is as the following.

\subsection{Mobile learning technology provides new ideas for deep learning of college students}

The fragmented and fast characteristics of mobile learning technology can provide new ideas for deep learning for college students. In university education activities, we can design phased, streamlined and practical thinking learning goals by grasping fragmented teaching resources. In mobile learning, goal orientation is an internal driving force that implements the entire learning process of college students. Therefore, it is necessary to grasp the fragmented teaching characteristics of mobile learning technology and design various phased and simplified deep learning goals. For example, at the beginning of teaching for college students, the first requirement is to cultivate students' interest in learning, to lay a solid foundation for students to form a good learning foundation, and to have sufficient determination to carry out deep learning activities. The second is to develop the cultivation of high-level thinking activities such as creative thinking of college students, so that students can have diversified thinking abilities. Finally, teachers should allow students to understand and criticize knowledge, connect and construct through these thinking activities, and form deep learning exploration. Therefore, in this teaching phase goal, the information technology and other means possessed by mobile learning technology can design phase learning goals for students. For example, in a micro-class video, only one learning goal is designed, and the design of the degree of relevance to the content of these micro-classes, the openness of ques- 
tions, etc. are realized, so as to promote the orderly development of deep learning activities for college students.

\subsection{Mobile learning technology provides new methods for deep learning for college students}

According to the above, mobile learning technology has promoted the formation of progressive teaching goals in deep learning activities for college students. The next step is to inspire college students to accept these learning goals with high efficiency and high quality, and promote the development of deep mobile learning activities. The mobile learning technology is to use diversified teaching methods and teaching techniques to effectively enhance learners' acceptance and provide learners with diversified teaching services. First of all, mobile learning technology provides students with moderately difficult learning tasks, learning problems and learning materials according to their different biological conditions, so that every learning step of college students can be carried out in a democratic and equal environment to avoid students competing with each other, which affects the learning efficiency of students. Secondly, mobile learning technology also builds efficient and usable mobile learning resources based on students' learning activities. With the support of information technology, the learning modules, assessment modules, evaluation and analysis modules in the mobile learning system can support students to complete in-depth learning activities. Finally, mobile learning technology can also provide various support services for deep learning activities. In the deep learning activities of college students, various support services will be needed, and mobile learning technology is playing such a functional role. For example, mobile learning technology can be combined with artificial intelligence to provide a one-to-one intelligent expert system for students' deep learning activities, so that various problems encountered in students' deep learning activities can be dealt with quickly and efficiently.

\section{Conclusion}

To sum up, deep learning is an important teaching goal method for quality education in the new era. By promoting students to develop deep learning, they can stimulate their enthusiasm and initiative in learning, and establish the critical thinking ability to analyze and solve problems. In this process, it effectively improves students' learning efficiency and quality, drives students' innovation and creativity, and forms advanced thinking skills. However, it is obvious that deep learning activities cannot be effectively carried out under traditional teaching techniques. Currently, with the support of science and technology, mobile learning technology is introduced to carry out deep learning activities for college students. On the one hand, it can change the singular teaching mode of traditional college student learning, and provide more resources and opportunities for stimulating students' autonomous learning activities. On the other hand, mobile learning technology creates a good learning atmosphere for college students' deep learning and provides richer learning services, effectively promoting students to carry out deep learning activities.

\section{References}

1. Liu L. Research on college English vocabulary teaching practice supported by mobile technology. Rural Economy and Technology 2016; 2722: 284+282.

2. Wu G, Yu W, Dai L. Research on the training mode and application of innovative and entrepreneurial talents based on mobile cloud learning technology. Journal of Distance Education 2017; 3504: 30-41.

3. Wang K, Ma X, Li X. Exploration of the path for mobile learning technology to promote the development of community education. Education Modernization 2017; 419: 47-48+51.

4. Zeng Z. Construction of a seamless learning environment for college English based on mobile learning technology. Journal of Heihe University 2020; 1104: 88-90. 